\title{
Strategi Pemasaran Pedagang Sembako Dalam Meningkatkan Taraf Ekonomi Perspektif Ekonomi Islam
}

\author{
Ismail Marzuki \\ Universitas Nurul Jadid (UNUJA) Paiton Probolinggo \\ Email: ismail.mz2805@gmail.com \\ Fatih Ramdaniah \\ Universitas Nurul Jadid (UNUJA) Paiton Probolinggo \\ Email:fatih001@yahoo.com
}

\begin{abstract}
Abstrak:
The development and competition of the business world in the current era of globalization is getting higher. This study aims to determine the marketing strategies of basic food traders in the pasar baru paiton. The method used is qualitative based on observation, interviews, and documentation. The results of the study showed that the marketing strategies carried out by nine basic necessities traders used several strategies, among others, (a) service strategies, not easily discouraged when experiencing losses or being lazy when they made large profits; (b) product strategy, punctuality and the speed of serving buyers can have an effect on reduced income; (c) price strategy, price openness is needed in trading, so that the product (bargaining) process can be mutually beneficial; (d) promotion strategies, where traders approach emotionally to foster consumer trust, while fostering a high social life. Nevertheless, there are some deviations in marketing practices, such as the presence of elements of gharar or obscurity, the element of coercion and selling merchandise below market prices.

[Perkembangan dan persaingan dunia bisnis di era globalisasi saat ini semakin tinggi. Penelitian ini bertujuan untuk mengetahui strategi pemasaran pedagang sembako di pasar baru paiton. Metode yang digunakan adalah kualitatif berdasarkan observasi, wawancara, dan dokumentasi. Hasil penelitian menunjukkan bahwa strategi pemasaran yang dilakukan pedagang sembako menggunakan beberapa strategi antara lain, (a) strategi pelayanan, tidak mudah putus asa ketika mengalami kerugian atau bersikap malas ketika mendapat keuntungan yang banyak; (b) strategi produk, ketepatan waktu buka dan kecepatan melayani pembeli dapat berpengaruh pada berkurangnya pemasukan; (c) strategi harga, keterbukaan harga diperlukan dalam berdagang, sehingga proses khiyar (tawar-menawar) produk dapat saling menguntungkan; (d) strategi promosi, di mana pedagang melakukan pendekatan secara emosional untuk menumbuhkan kepercayaan konsumen, sekaligus memupuk jiwa sosial yang tinggi. Kendati demikian, terdapat beberapa penyimpangan dalam praktik pemasarannya, seperti adanya unsur gharar atau ketidakjelasan, adanya unsur pemaksaan dan menjual barang dagangan dibawah harga pasar.]
\end{abstract}

Kata Kunci: Strategi; Pemasaran; Pedagang Sembako. 


\section{PENDAHULUAN}

Sebelum lebih jauh memahami istilah "strategi pemasaran", terlebih dahulu perlu diuraikan masing-masing makna dari istilah tersebut. Hal ini diharapkan dapat membantu memberikan pemahaman secara utuh tentang arah penelitian ini. Pasar merupakan salah satu pusat terjadinya kegiatan-kegiatan transaksi ekonomi. Secara sederhana strategi adalah suatu rencana yang utama untuk mencapai tujuan. ${ }^{1}$ Menurut definisi Rosyidi pasar adalah sebentuk organisasi dimana kedua pihak yang melakukan transaksi ekonomi (penjual dan pembeli) terhubung dengan hubungan yang erat.2 Sementara pasar dalam Kamus Besar Bahasa Indonesia (KBBI) dimaknai sebagai tempat orang berjual beli atau tempat penjual yang ingin menukar barang atau jasa dengan uang dan pembeli yang ingin menukar uang dengan barang atau jasa. ${ }^{3}$ Dari pengertian tersebut dapat dipahami bahwa pasar merupakan tempat bertemunya penjual dan pembeli untuk melakukan transaksi pertukaran kepemilikan atau jual beli, baik berupa uang dengan barang atau uang dengan jasa. Dari kata pasar kemudian lahir istilah pemasaran yang sebagai suatu kegiatan dalam perekonomian yang membantu dalam menciptakan nilai-nilai ekonomi. ${ }^{4}$ Jadi dapat disimpulkan strategi pemasaran adalah langkah yang akan dilakukan dalam kegiatan pemasaran untuk meraih tujuan dan bisa menjadi pemimpin pasar. ${ }^{5}$ Strategi pemasaran mempunyai peran yang sangat penting bagi pengusaha atau pedagang yang bekerja dalam persaingan pasar. ${ }^{6}$ Dalam menghadapi persaingan pasar yang semakin ketat dibutuhkan strategi pemasaran untuk menjangkau peluang pasar maupun sasaran yang memungkinkan. Sehingga pedagang mampu memanfaatkan sumber daya yang dimiliki untuk meningkatkan nilai jual.

Dalam sebuah artikel "Strategi Pemasaran Dalam Perspektif Ekonomi Islam (Studi Kasus Pedagang di Pasar Tradisional)" yang ditulis Jasman dan Rini Agustin yang dimuat dalam Khozana (Vol. 1, Januari 2018) dibahas mengenai strategi pemasaran pedagang sayuran di Pasar Tradisional Raman Utara dalam perspektif ekonomi Islam dan alasan pedagang melakukan dugaan penyimpangan. Menurut Jasman dan Agustin, strategi pemasaran yang dilakukan oleh pedagang sayuran ada yang sesuai dengan ekonomi Islam seperti bertindak jujur, amanah dan murah hati. Akan tetapi masih ada beberapa yang tidak sesuai seperti dalam hal mengurangi timbangan, reklame palsu, menyembunyikan cacat barang dan sumpah palsu. selain artikel tersebut juga ada skripsi berjudul "Strategi Pemasaran Pedagang Pasar Tradisional Dalam Perspektif Ekonomi Islam (Studi Kasus di Pasar Lebaksiu-Tegal)" yang ditulis Nur Faeni Ulyati pada tahun 2015 mahasiswi Fakultas Ekonomi dan Bisnis Islam Universitas Islam Negeri Walisongo Semarang. Menurut hasil penelitiannya mengenai strategi pemasaran pedagang Pasar Tradisional Lebaksiu Tegal, produk yang diperdagangkan sudah memenuhi aspek kehalalan dan boleh diperdagangkan. Akan tetapi, masih ada beberapa pedagang yang mencampurkan produk barang berkualitas baik dengan yang berkualitas biasa/buruk tanpa ada kejujuran di dalamnya.

\footnotetext{
1 Sareeha Tahlohding, 'Pemasaran Dalam Ekonomi Islam Studi Integrasi Dan Komprehensif', Hukum Islam, XV.1 (2015), 230-43.

2 Suherman Rosyidi, Pengantar Teori Ekonomi Pendekatan Kepada Teori Ekonomi Mikro \& Makro Jakarta: Rajawali Pers, 2006, 402.

3 "Arti Kata Pasar-Kamus Besar Bahasa Indonesia (KBBI) Online," diakses 29 Januari 2019, http://kbbi.web.id/pasar.

${ }^{4}$ Kamaruddin, 'Strategi Pemasaran Terhadap Peningkatan Volume Penjualan Gas Elpiji Perspektif Ekonomi Islam', Laa Maisyir, 4.1 (2017), 81-96.

5 Akila, 'Menjaring Konsumen Dengan Konsep Beriontasi Strategi Pemasaran', Jurnal Media Wahana Ekonomika, 11.3 (2014), $84-89$.

6 Jasman dan Rini Agustin, 'Strategi Pemasaran Dalam Perspektif Ekonomi Islam (Studi Kasus Pedagang di Pasar Tradisional)', Khozana, 1.1 (2018), 65-95.
} 
Penelitian yang dilakukan oleh Jasman dan Agustin maupun penelitian yang dilakukan oleh Ulyati di atas memang menarik, namun mereka hanya mengkaji sekilas tentang strategi pemasaran yang digunakan oleh pedagang dalam perspektif ekonomi Islam tanpa menawarkan konsep strategi pemasaran perspektif ekonomi Islam sebagai kunci maupun pedoman dalam meningkatkan pendapatan dan suksesnya bisnis yang dijalankan. Salah satu kasus yang sangat menarik untuk dikaji lebih dalam bisa dilihat di Pasar Baru Paiton Probolinggo. Pasar Baru Paiton begitu masyarakat menyebutnya, merupakan pasar terbesar se kecamatan Paiton. Di dalamnya banyak ditawarkan berbagai macam produk, mulai dari pakaian, kuliner, hingga berbagai kebutuhan rumah tangga sehari-hari (sembako).

Penelitian ini akan mengkaji tentang strategi pemasaran pedagang sembako di Pasar Baru Paiton. Dipilihnya pedagang sembako dikarenakan beberapa hal, yakni; di samping karena sembako menjadi objek utama masyarakat ketika pergi ke pasar, juga dalam prakteknya transaksi yang dilakukan masih belum sepenuhnya berdasarkan pada syariat Islam lantaran minimnya pengetahuan pedagang. Sehingga masih ada beberapa pedagang sembako yang kurang baik dalam melakukan pemasarannya, seperti menjual dibawah harga pasar ataupun adanya unsur gharar pada takaran maupun kualitas barang. Pemasaran yang kurang baik tersebut dapat berdampak pada rusaknya citra pedagang dan hilangnya kepercayaan konsumen karena merasa kecewa dan dirugikan. Kekecewaan tersebut dapat membuat mereka enggan untuk membeli kembali sehingga pemasaran terhadap barang dagang juga terhambat. Mengingat hal tersebut, strategi pemasaran dalam perspektif ekonomi Islam merupakan kunci maupun solusi bagi pedagang dalam memanfaatkan peluang pasar dengan seefisien mungkin. Strategi pemasaran dalam perspektif ekonomi Islam adalah suatu konsep atau rencana yang dapat membantu mensukseskan pemasaran dengan tetap berpegang atau berpedoman pada nilai-nilai yang mengandung unsur kemaslahatan.

Berdasarkan paparan di atas, penelitian ini dilakukan untuk menjawab fokus masalah dalam penelitian ini, yakni mengenai strategi pemasaran apa saja yang digunakan oleh pedagang sembako dalam meningkatkan pendapatan, dan Analisis ekonomi Islam terhadap strategi pemasaran yang dilakukan oleh pedagang sembako di Pasar Baru Paiton.

\section{METODOLOGI PENELITIAN}

Jenis penelitian ini adalah penelitian lapangan dan metode yang digunakan pada penelitian ini adalah metode kualitatif. Populasi pada penelitian ini adalah seluruh pedagang sembako di Pasar Baru Paiton Probolinggo yang berjumlah sekitar 23 pedagang. Sumber data yang digunakan yakni data primer dan data sekunder. Data primer diperoleh langsung dengan cara observasi, wawancara secara mendalam, dan dokumentasi mengenai tinjauan yang menjadi fokus pada penelitian ini. Data sekunder diperoleh dari riset kepustakaan yang dijadikan sebagai landasan teori guna sebagai acuan agar peneliti tidak melewati batasan dalam menganalisis data yang diperoleh di lapangan. Pengolahan data menggunakan metode analisis deskriptif dan analisis induktif dengan menggambarkan strategi pemasaran yang digunakan oleh pedagang sembako, kemudian menganalisanya berdasarkan tinjauan ekonomi Islam.

\section{HASIL DAN PEMBAHASAN}

Dari hasil observasi dan wawancara dapat diketahui bahwa Pasar Baru Paiton merupakan salah satu pasar yang didalamnya terjadi begitu banyak aktifitas transaksi ekonomi pada setiap harinya, baik dalam skala kecil maupun dalam skala besar. Pasar Baru Paiton adalah salah satu pasar yang ada di kabupaten probolinggo dan berada dalam naungan Dinas Pendapatan. 
Sebagaimana yang kita ketahui pasar merupakan tempat terjadinya aktifitas transaksi ekonomi dimana aktifitas transaksi ekonomi tersebut terjadi atau berlangsung secara alamiah sehingga timbul beberapa nilai moralitas secara alamiah pula. Hal ini sejalan dengan pendapat Farida (2012) yang menyatakan bahwa Islam memberikan penghargaan yang tinggi atas mekanisme pasar yang berlandaskan pada ketentuan Allah Swt. Allah Swt menegaskan bahwa perniagaan harus dilakukan secara baik atas rasa suka sama suka serta menjunjung nilai moralitas mutlak. Nilai-nilai moralitas yang mendapatkan perhatian khusus dalam mekanisme pasar adalah persaingan yang sehat, berasaskan kejujuran, keterbukaan, dan keadilan. ${ }^{7}$ Secara umum mekanisme pasar merupakan proses dalam penentuan tingkat harga berdasarkan kekuatan permintaan dan penawaran. Pertemuan antara permintaan (demand) dan penawaran (supply) dapat menciptakan harga keseimbangan (equilibrium price). ${ }^{8}$ Pasar memiliki fungsi sebagai penentu nilai suatu barang, jumlah produksi, luas pendistribusian produk, pembatasan terhadap harga, serta menyediakan barang dan jasa untuk jangka panjang. ${ }^{9}$

Mengingat beberapa fungsi pasar tersebut peluang bisnis sembako dipandang cukup menjanjikan karena menyajikan barang dagangan untuk kebutuhan pokok sehari-hari dan dianggap memiliki sedikit tingkat resiko kerugian. Dalam berbisnis tentunya dibutuhkan strategi pemasaran yang tepat untuk meminimalisir terjadinya kerugian yang sangat tinggi. Hal ini sejalan dengan pengertian strategi yang merupakan suatu metode yang sudah terstruktur rapi dan digunakan oleh organisasi untuk mencapai tujuan tentunya dengan efisien dan seefektif mungkin sehingga mendapatkan hasil yang lebih menguntungkan. Istilah strategi terkait dengan hasil yang lebih baik tentunya dengan penekanan agar resiko yang akan dihadapi lebih rendah. ${ }^{10}$ Strategi menjadi petunjuk atau pedoman bagi perusahaan maupun pedagang dalam usahanya untuk mencapai tujuan utamanya. ${ }^{11}$ Strategi perusahaan selalu diprioritaskan untuk mendapatkan atau menuju hasil kinerja pemasaran yang lebih baik dan kinerja keuangan yang baik pula. ${ }^{12}$

Pemasaran diibaratkan sebagai suatu medan tempur bagi produsen dan para pedagang yang bergerak pada komoditi yang sama, maka perlu diciptakan suatu strategi pemasaran yang terencana dengan rapi, agar dapat memenangkan peperangan tersebut.13 Pemasaran menurut Philip Kotler yang dikutip oleh Idri dalam bukunya menyatakan bahwa pemasaran adalah bekerja bersama untuk mewujudkan pertukaran yang potensial dengan maksud memuaskan keinginan dan kebutuhan konsumen.14 Sedangkan pemasaran menurut perspektif syariah merupakan segala aktivitas yang berkaitan dengan kegiatan bisnis dalam bentuk kegiatan penciptaan nilai (value creating activities) untuk memungkinkan siapa saja yang melakukannya dapat tumbuh serta mendayagunakan manfaatnya dan dilandasi atas

\footnotetext{
7 Ulfa Jamilatul Farida, 'Telaah Kritis Pemikiran Ekonomi Islam Terhadap Mekanisme Pasar Dalam Konteks Ekonomi Islam Kekinian', La Riba Jurnal Ekonomi Islam, VI.2 (2012), 257-70.

8 Euis Amalia, 'Mekanisme Pasar Dan Kebijakan Penetapan Harga Adil Dalam Perspektif Ekonomi Islam', AlIqtishaq, V.1 (2013), 1-22.

9 \& Bahrul Ulum Rusydi Muh. Ihsan, Wahidah Abdullah, 'Implementasi Prinsip Ekonomi Islam Oleh Pedagang Dalam Melakukan Penimbangan Sembako Di Pasar Soppeng', An-Nisbah: Jurnal Ekonomi Syariah, 05.01 (2018), 381-96.

${ }^{10}$ Abdul Halim Usman, Manajemen Strategi Syariah: Teori, Konsep, \& Aplikasi Jakarta: Zikrul Hakim, 2015, 72.

11 Yenni Yuniarti \& Sarah Mauliana, 'Strategi Pemasaran Produk Digital Printing Pada CV. FNB Digital Jambi, 1.1 (2012), 31-39.

12 Aris Mardiyono, 'Pengaruh Orientasi Pasar, Pembelajaran Organisasi Terhadap Keunggulan Bersing Dalam Meningkatkan Kinerja Pemasaran (Tinjauan Teoritis)', Serat Acitya: Jurnal Ilmiah, 04.01, (2015) 48-59.

13 Buchari Alma, Kewirausahaan Bandung: Alfabeta, 2013, 195.

14 Idri, Hadis Ekonomi: Ekonomi Dalam Perspektif Hadis Nabi Jakarta: Kencana, 2015, 263.
} 
sifat jujur, adil, terbuka, serta ikhlas sesuai dengan proses yang berprinsipkan kepada etika dalam kegiatan bermuamalah secara Islami atau kegiatan transaksi bisnis dalam Islam. ${ }^{15}$

Strategi pemasaran itu sendiri adalah memilih dan menganalisa pangsa pasar yang merupakan suatu kelompok orang yang menjadi sasaran perusahaan, dapat menciptakan bauran pemasaran yang sesuai dan bisa memberikan kepuasan pada pangsa pasar sasaran tersebut.16 Menurut Bukhari Alma dan Donni Juni Priansa, pemasaran dalam Islam merupakan sebuah disiplin ilmu bisnis strategis yang akan mengarahkan dalam proses penciptaan, penawaran, dan perubahan nilai dari satu inisiator kepada stakeholders-nya, yang keseluruhan prosesnya sesuai dengan etika berbisnis serta prinsip-prinsip al-Qur'an dan hadits. ${ }^{17}$

Dalam dunia bisnis strategi pemasaran merupakan wujud rencana atau konsep yang terarah di bidang pemasaran, untuk memperoleh suatu bauran hasil yang optimal. ${ }^{18}$ Namun sebagai seorang muslim dalam menjalankan bisnis harus berpegang pada dua unsur kemaslahatan, baik kemaslahatan secara vertikal (Tuhan) maupun kemaslahatan secara horizontal (sesama manusia). Jadi harus ada keseimbangan antara kehidupan dunia dan akhirat, sebagaimana hadits yang diriwayatkan Ibnu Majah, sebagai berikut:

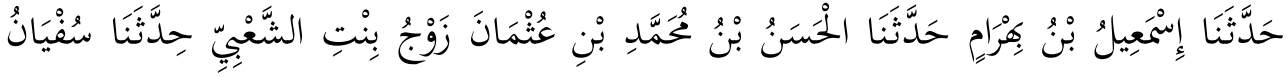

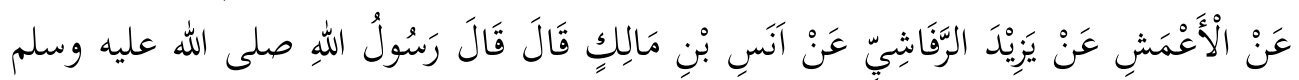

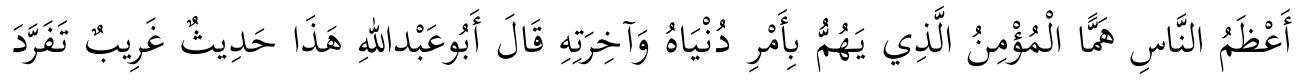

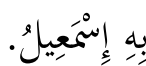

Artinya: "Nabi Saw. bersabda "Orang yang paling besar cita-citanya adalah orang memikirkan atau bercita-cita untuk urusan dunia dan akhiratnya".19

Mengingat hal itu, strategi pemasaran dalam perspektif ekonomi Islam adalah suatu konsep atau rencana yang dapat membantu mensukseskan pemasaran dengan tetap berpegang atau berpedoman pada nilai-nilai yang mengandung unsur kemaslahatan. Hal ini didukung oleh hadits yang menyatakan bahwa seseorang yang memasuki pasar untuk berbisnis dan menyerahkan apa yang ia usahakan pada Allah Saw maka ia akan diberi kebaikan yang berlipat. Sebagaimana hadits yang diriwayatkan Ibnu Majah, sebagai berikut:

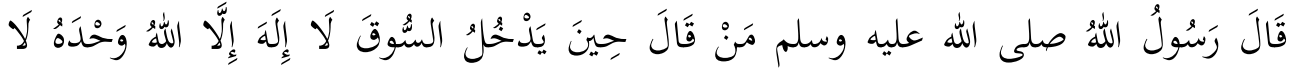

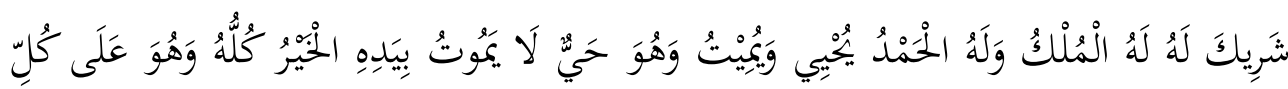

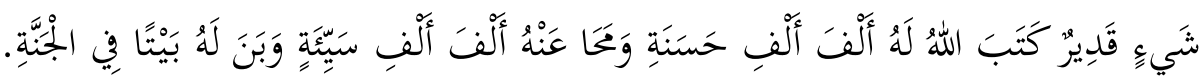

Artinya: "Rasulullah Saw. bersabda "Barang siapa berkata ketika memasuki pasar: 'Tidak ada Tuhan selain yang Esa, tiada yang menyamai, bagi-Nya kekuasaan, segala puji milik-Nya, zat yang menghidupkan dan mematikan, Ia maha hidup, tidak akan mati, di tangan-Nya segala kebaikan, maha kuasa atas

\footnotetext{
15 Tamamudin, 'Merefleksikan Teori Pemasaran Ke Dalam Praktik Pemasaran Syariah', Jurnal Hukum Islam (JHI), 12.2 (2014), 273-85.

16 Alma, 195.

17 Kamaruddin.

18 Jasman dan Rini Agustin.

19 Ilfi Nur Diana, Hadis - Hadis Ekonomi (Malang: UIN Maliki Perss, 2012), hlm. 9.
} 
segala sesuatu', maka Allah akan menulis sejuta kebaikan dan menolak sejuta keburukan, dan akan membangunkan rumah di surga".20

Selain itu, pedagang juga harus memiliki prinsip yang dapat menjaga dirinya agar tidak terjerumus dalam jenis-jenis transaksi yang merugikan, baik kepada dirinya maupun orang lain. Terdapat Sembilan (9) etika/akhlak yang dikutip oleh Tamamuddin yang menjadi prinsip utama bagi pedagang, yaitu sebagai berikut 1) Memilki kepribadian spiritual (takwa), 2) Berperilaku baik dan simpatik (shidiq), 3) Berlaku adil dalam bisnis (al-adl), 4) Bersikap melayani dan rendah hati (khidmah), 5) Menepati janji dan tidak curang, 6) Jujur dan terpercaya (amanah), 7) Tidak suka berburuk sangka (su'uzh-zhan), 8) Tidak suka menjelekjelekan (ghibah), 9) Tidak melakukan sogok (riswah) ${ }^{21}$

\section{Strategi Pemasaran Pedagang Sembako di Pasar Baru Paiton}

Dari hasil observasi maupun wawancara menunjukkan jumlah pedagang sembako yang tersebar di Pasar Baru Paiton sekitar 23 pedagang sembako. ${ }^{22}$ Penulis akan menyajikan data 10 sampel dari hasil observasi dan wawancara langsung kepada pedagang sembako di Pasar Baru Paiton. Dari data yang didapat, secara keseluruhan pedagang sembako beragama Islam dengan rata-rata pengalaman dagang sekitar 7 -15 tahun, dan jumlah pendapatan berkisar antara Rp. 2.000.000,- hingga Rp. 4.500.000,- perbulan. Dapat diketahui pula bahwa strategi pemasaran yang dilakukan oleh pedagang sembako di Pasar Baru Paiton ialah sebagai berikut:

\section{Strategi Pelayanan}

Untuk memenuhi kebutuhan yang semakin tinggi, sebagai pedagang mereka harus bisa menjual dagangannya sebanyak mungkin. Dari beberapa keterangan pedagang sembako dapat disimpulkan bahwa pelayanan berdampak pada pengambilan keputusan pembeli dalam berbelanja kebutuhannya. Strategi pelayanan yang dilakukan oleh pedagang sembako, seperti melayani dengan sabar, ramah, murah senyum, melayani kebutuhan konsumen dengan cepat, memberikan kesan yang baik, dan membuat konsumen merasa nyaman saat berbelanja. Hal ini sesuai dengan yang disampaikan Alma bahwa seorang muslim bila menjual barang, harus dengan senang hati, gembira, ikhlas, dan memberikan kesan yang baik terhadap pembeli.23 Pelayanan yang demikian ternyata mampu meningkatkan jumlah penjualan pedagang. Kendati demikian, menurut salah satu pembeli, masih ada beberapa pedagang sembako yang tidak terlalu ramah dalam melayani pembelinya dan hanya bertanya atau menjawab seperlunya saja bahkan terkesan ketus, sehingga membuat dirinya (pembeli) merasa kurang dihargai.

\section{Strategi Produk}

Strategi produk yang dilakukan pedagang sembako yaitu memanfaatkan waktu seefisien dan efektif mungkin dengan memperhatikan dua hal, yaitu ketepatan memulai usaha dan melayani pembeli dengan cepat. Menurut mereka ketepatan waktu memulai berdagang dan kecepatan dalam melayani pembeli berdampak pada banyak atau sedikitnya jumlah produk yang terjual. Dalam arti semakin banyak pembeli yang bisa dilayani semakin banyak pula barang dagang yang bisa terjual.

\footnotetext{
20 Diana, 4-6.

21 Tamamudin.

22 Wawancara Bpk. Ach Faruq selaku staf di kantor Pasar Baru Paiton Probolinggo. Pada Hari Senin, 24 Desember 2018. Jam 10:30 AM.

${ }^{23}$ Alma, 249.
} 
Dari hasil wawancara diketahui bahwa ada beberapa pedagang sembako di Pasar Baru Paiton yang menyediakan beberapa kualitas pada satu jenis barang. Barang tersebut sudah berada dalam kemasan yang sudah ditimbang oleh pedagang sehingga ketika ada pembeli yang ingin membeli barang tersebut, pedagang bisa langsung mengambilkannya. Perdagangan yang seperti ini tidak diperbolehkan karena mengandung unsur gharar (ketidakjelasan) baik dari segi timbangan maupun kualitas. Karena bisa jadi barang yang sudah dikemas dan ditimbang sendiri oleh pedagang dikurangi takaran timbangannya atau barang tersebut telah dicampur dengan barang jenis yang sama namun beda dari sisi kualitas. Hal ini terbukti ketika penulis melakukan observasi ada pedagang yang menjual telur yang sudah dikemas dan dalam kemasan tersebut terdapat telur yang sudah retak.

\section{Strategi Harga}

Strategi harga yang digunakan pedagang sembako, seperti melakukan keterbukaan antara harga dan keuntungan yang diperoleh, menjual dengan keuntungan dibawah pedagang lainnya dan memberikan diskon atau potongan harga kepada pembeli. Semua strategi dilakukan untuk meningkatkan penjualan dan mempertahankan loyalitas pembeli.

Dalam perdagangan ada beberapa yang perlu diperhatikan terutama dalam menawarkan harga dan mengambil keuntungan. Menawarkan barang dagangan hendaknya dilakukan dengan harga yang sewajarnya. Dalam arti harga yang ditawarkan tidak teralu mahal sehingga banyak memberi keuntungan bagi pedagang dan merugikan pembeli atau sebaliknya. Pedagang sembako di Pasar Baru Paiton masih ada yang menawarkan harga dibawah harga pasar. Dengan cara mengambil keuntungan yang lebih sedikit dari pedagang lainnya. Hal ini dilakukan agar di satu sisi, semakin banyak pembeli yang datang, dan secara bersamaan semakin banyak produk yang terjual.

Abu Yusuf menyatakan bahwa tidak ada batasan tertentu tentang murah dan mahalnya harga di pasar. Murah bukan karena melimpahnya makanan, demikian juga mahal bukan karena kelangkaan makanan, terkadang makanan sedikit namun harganya murah. Murah dan mahal merupakan ketentuan Allah Swt. ${ }^{24}$ Sedangkan Ibnu Taimiyah menyatakan bahwa naik turunnya harga tidak selalu disebabkan oleh tindakan tidak adil dari sebagian orang yang terlibat transaksi pertukaran. Bisa jadi yang menjadi penyebab adalah penawaran yang menurun akibat inefisiensi produksi, penurunan jumlah impor barang-barang yang diminta atau tekanan pasar. ${ }^{25}$ Oleh karena itu ambillah keuntungan sewajarnya dan naikkanlah harga sewajarnya sesuai dengan harga pasar agar tidak ada pihak yang merasa dirugikan.

\section{Strategi Promosi}

Strategi promosi yang dilakukan pedagang sembako, antara lain dilakukan melalui pendekatan emosional dengan jalan bersilaturahmi kepada pembeli. Hal ini dilakukan untuk meningkatkan kepercayaan dan menciptakan komitmen antara kedua pihak, yakni penjual dan pembeli. Selain itu, ada juga pedagang sembako yang memberi kesempatan kepada pembeli dalam melakukan transaksi secara kredit, di samping juga memberikan hadiah di waktu tertentu kepada pelanggan setia, baik berupa pakaian maupun makanan, umumnya hal ini diberikan ketika menjelang hari raya idul fitri.

Selain beberapa strategi promosi yang dilakukan pedagang sembako di atas. Penulis juga menemukan seorang pedagang yang menelfon pembelinya ketika melihat pembelinya bertanya beras ke pedagang lain di pasar. Dengan mengatakan bahwa ia juga memiliki

${ }^{24}$ Rozalinda, Ekonomi Islam Teori Dan Aplikasinya Pada Aktivitas Ekonomi Jakarta: Rajawali Pers, 2015, 149.
${ }^{25}$ Adiwarman A. Karim, Ekonomi Mikro Islami Jakarta: Rajawali Pers, 2016, 170. 
persedian barang yang dicari oleh pembelinya. Perbuatan yang dilakukan oleh pedagang sembako tersebut tentu tidak dibenarkan karena mengandung unsur paksaan meski dilakukan tanpa kesengajaan, karena secara tidak langsung penjual telah memaksa pembeli tersebut untuk tetap membeli beras di tempatnya.

\section{Analisis Strategi Pemasaran Pedagang Sembako di Pasar Baru Paiton dalam Meningkatkan Taraf Ekonomi Perspektif Ekonomi Islam}

Berdasarkan hasil penelitian yang dilakukan di Pasar Baru Paiton, dapat diketahui bahwa strategi pemasaran yang digunakan pedagang sembako, meliputi; strategi pelayanan; strategi produk; strategi harga; dan strategi promosi.

Adapun analisis tinjuan ekonomi Islam terhadap empat strategi pemasaran yang digunakan pedagang sembako tersebut ialah sebagai berikut:

Pertama, Strategi Pekayanan. Perdagangan merupakan salah satu kegiatan ekonomi yang diatur dalam Islam. ${ }^{26}$ Hal yang akan selalu dijumpai oleh seorang pedagang adalah untung dan rugi. Oleh karena itu, menerapkan sikap istiqomah itu sangat dianjurkan bagi orang yang hendak berbisnis agar tidak mudah putus asa ketika mengalami kerugian atau bermalas-malasan karena merasa sudah mendapatkan keuntungan yang banyak. Istiqomah dalam berbisnis berkaitan dengan niat, ucapan dan perilaku sehari-hari. Sebagai seorang pedagang dianjurkan untuk melayani pembeli dengan sebaik mungkin. Begitu pula dengan pedagang sembako di Pasar Baru Paiton, mereka melayani pembeli dengan ramah, murah senyum, dan sabar agar pembeli merasa nyaman saat berbelanja. Hal ini sejalan dengan hadits Nabi Muhammad Saw., sebagai berikut:

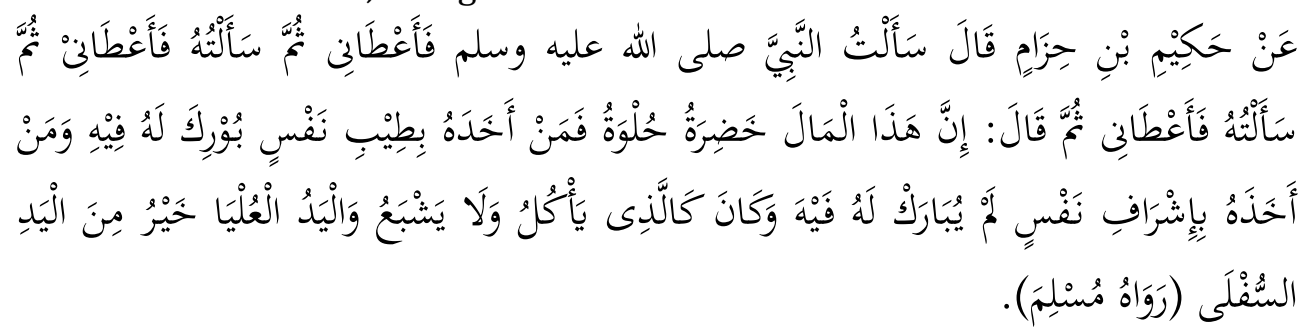

Artinya, "Dari hakim ibn Hizam, katanya: aku meminta (sesuatu) kepada Nabi Saw. Lalu ia memberikannya kepadaku kemudian aku memintanya lagi dan memberikan kepadaku, lalu aku meminta lagi dan ia memberiku lagi. Kemudian Nabi bersabda, "Sesungguhnya harta ini hijau (indah) lagi manis. Barang siapa yang mengambilnya dengan jiwa yang baik, maka akan diberkahi dan barang siapa yang mengambilnya dengan jiwa yang boros, maka tidak akan diberkahi seperti orang makan tapi tidak kenyang-kenyang. Tangan di atas lebih baik dari pada tangan di bawah" (HR. Muslim). ${ }^{27}$

Berdasarkan hadits di atas dapat dipahami bahwa dengan memberikan pelayanan terbaik dengan menciptakan kesan nyaman pada pembeli saat berbelanja maka usaha yang dijalankan akan diberkahi sehingga bukan hanya kebutuhan yang akan terpenuhi tetapi bisnis yang dijalankan juga sukses.

Kedua, Strategi Produk. Proyeksi utama seorang pedagang adalah keuntungan yang tinggi. Keuntungan tersebut bisa diperoleh ketika pedagang mampu menjual banyak barang. Tepat waktu dalam memulai usaha menjadi salah satu faktor yang berpengaruh pada

${ }^{26}$ Bahrul Ulum Rusydi Muh. Ihsan, Wahidah Abdullah, 'Implementasi Prinsip Ekonomi Islam Oleh Pedagang Dalam Melakukan Penimbangan Sembako Di Pasar Soppeng', An-Nisbah: Jurnal Ekonomi Syariah, 05.01 (2018), 381-96.

27 Idri, hlm. 334-335. 
pendapatan penjualan. Jika seorang pedagang tidak konsisten dalam memulai usahanya akan sering kali membuat pembeli merasa kecewa dan beralih pada pedagang lain. Kerugian atas tidak konsistennya dalam memulai usaha merupakan hasil dari perbuatannya. Sebagaimana firman Allah Swt. sebagai berikut:

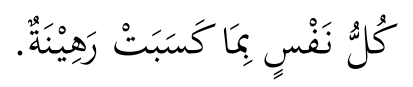

Artinya: "Tiat-tiap diri bertanggung jawab atas apa yang telah diperbuatnya" (QS. Al-Muddatstsir: 38).28

Selain itu, dalam menjual barang dagangan tidak diperkenankan ada unsur gharar (ketidakjelasan) baik dalam segi timbangan maupun kualitas barang. Rasulullah Saw bersabda:

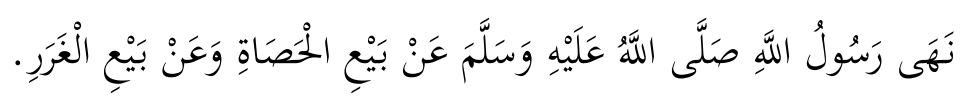

Berdasarkan hadits di atas, Rasulullah Saw sangat melarang jenis transaksi yang mengandung unsur gharar, karena dapat dipastikan di dalamnya terdapat harta orang lain yang diambil secara batil. Mengambil/memakan harta orang lain secara batil sangat bertentangan dengan prinsip-prinsip ekonomi Islam yang harus dipegang teguh oleh seorang pedagang, yakni bertakwa, shiddiq, dan adil.

Ketiga, Strategi Harga. Keterbukaan atau transparan dalam masalah harga sangat dianjurkan dalam Islam, dengan syarat harga dan keuntungan yang disebutkan adalah harga dan keuntungan yang sebenarnya. Hal ini yang dipraktekkan langsung oleh Rasulullah Saw ketika beliau menjalankan bisnis berdagangnya ke Negeri Syam. Adanya keterbukaan harga tersebut dibutuhkan untuk menjaga kepercayaan pembeli. Begitupula dalam menawarkan harga dan mengambil keuntungan harus dilakukan dengan sewajarnya.

Selain itu, Islam tidak menganjurkan menjual barang dagangan di bawah harga pasar karena perbuatan tersebut dapat mengganggu stabilitas harga barang di pasar dan merugikan pedagang yang lain. Begitupun sebaliknya, menawarkan harga dan keuntungan lebih tinggi dari pedagang lainnya juga tidak dianjurkan karena bisa membuat pembeli merasa dirugikan atau tertipu dengan harga yang dipasarkan. Apalagi perdagangan yang mengandung unsur penipuan itu dilarang dalam Islam, sebagaimana hadits Nabi Muhammad Saw, sebagai berikut:

$$
\text { عن ابي هريرة قال فهى رسول الله صلى الله عليه وسلم عن بيع الحصاة وعن بيع الغرر (رواه }
$$

Artinya: "Dari Abu Hurayah r.a., katanya, "Rasulullah melarang jual beli dengan cara melempar dan jual beli yang mengandung penipuan". (HR. Muslim). ${ }^{29}$

Keempat, Strategi Promosi. Dalam menjalankan sebuah bisnis, memperluas relasi merupakan salah satu faktor yang dapat memperlancar bisnis yang ditekuni. Menjalin relasi dalam ajaran Islam disebut dengan istilah silaturrahmi. Dengan bersilaturrahmi, kedekatan dan kepercayaan (trust) di antara pedagang dan pembeli akan tumbuh dan terbangun dengan kuat. Apabila kepercayaan dan komitmen sudah tercipta di antara kedua pelaku transaksi pertukaran, maka hasil yang diperoleh akan jauh lebih efisien, efektif dan produktif. ${ }^{30} \mathrm{Hal}$ di

\footnotetext{
28 'Al-Qur'an Terjemah Disertai Ayat-Ayat Do'a Ayat-Ayat Keutamaan Al-Qur'an Ayat-Ayat Tazkiyatun Nafs Dan Hadits Keutamaan Al-Qur'an' (Pustaka Al-Mubin).

${ }^{29}$ Idri, hlm. 331.

30 Robert Kristaung, 'Strategi Relationship Marketing: Kajian Teoritis Dan Implikasinya Dalam Manajemen Pemassaran', Jurnal Manajemen Krida Wacana, 5.2 (2005), 113-26.
} 
atas sesuai dengan hadits Nabi Muhammad Saw yang diriwayatkan oleh Bukhari dan Muslim, sebagai berikut:

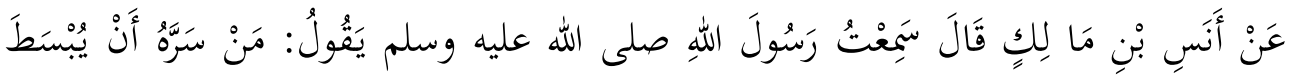

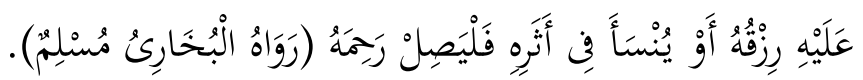

Artinya "Dari Anas ibn Malik, katanya: Aku mendengar Rasulullah Saw. Bersabda 'Barangsiapa ingin agar rezekinya dilapangkan dan pengaruhnya di luarsan, maka hendaklah ia meyambung tali silaturrahmi." (HR. al-Bukhari dan Muslim). ${ }^{31}$

Hadits di atas merupakan jaminan Allah bahwa silaturrahmi yang dilakukan oleh seseorang mampu membuat lapang jalan rizki orang tersebut. Di samping itu, hal yang tidak boleh dilupakan bagi seorang pedagang adalah bagaimana menanamkan jiwa sosial yang tinggi kepada siapapun, termasuk kepada para pembeli, mengingat para pembeli berasal dari berbagai kalangan dan memiliki kemampuan secara finansial yang tidak serupa. Jiwa sosial ini dipraktekkan oleh beberapa pedagang sembako di Pasar Baru Paiton yakni dengan memberi kesempatan melakukan kredit kepada pembeli ketika ada kebutuhan mendesak dan belum mampu membayar cash karena keterbatasan dana yang dimiliki. Hal ini sesuai dengan hadits Nabi Muhammad Saw., sebagai berikut:

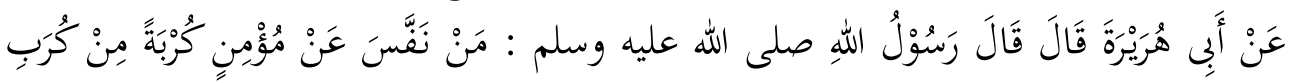

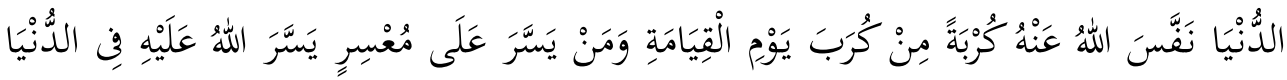

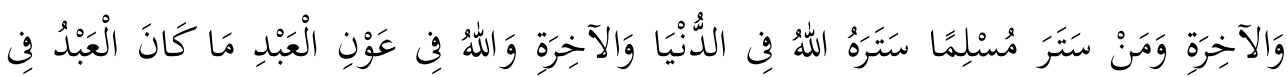

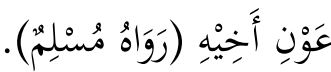

Artinya: "Dari Abu Hurayrah katanya: Rasulullah Saw. bersabda, "Barangsiapa meringankan kesusahan duniawi dari seorang mukmin, maka Allah akan meringankan darinya kesusahan akhirat, barangsiapa mempermudah orang mendapat kesulitan, maka Allah akan mempermudahnya di dunia dan akhirat, dan barangsiapa menutupi (aib) seorang Muslim, maka Allah akan menutupi (aibnya) di dunia san akhirat. Allah akan menolong seorang hamba selama hamba itu suka menolong saudaranya". (HR. Muslim). ${ }^{32}$

\section{Penutup}

Berdasarkan uraian pembahasan dalam penelitian ini, dapat disimpulkan bahwa strategi yang digunakan oleh pedagang sembako di Pasar Baru Paiton meliputi empat (4) hal, yakni strategi pelayanan, strategi produk, strategi harga, dan strategi promosi. Dalam perspektif ekonomi Islam, strategi pemasaran yang dilakukan oleh pedagang sembako di Pasar Baru Paiton sebagian besar telah sesuai dengan nilai-nilai ekonomi Islam, seperti; (a) melayani pembeli dengan baik dan ramah; (b) adanya keterbukaan mengenai harga dan keuntungan yang diperoleh; (c) menjalin silaturrahmi untuk meningkatkan kepercayaan dan komitmen kedua pihak; (d) menanamkan jiwa sosial kepada siapa saja, termasuk kepada pembeli. Dalam penerapan beberapa strategi tersebut, pedagang sembako di Pasar Baru Paiton mendapatkan keuntungan yang signifikan. Meski demikian, masih terdapat sebagian kecil pedagang sembako yang kurang baik dalam menerapkan strategi pemasaran barang

31 Idri, hlm. 270.

32 Idri, hlm. 343-344. 
dagangannya, seperti; (a) adanya unsur gharar (ketidakjelasan); (b) adanya unsur pemaksaan; (c) bersikap acuh atau ketus; dan (d) menjual barang dagangan dibawah harga pasar.

\section{DAFTAR PUSTAKA}

Al-Qur'an Terjemah Disertai Ayat-Ayat Do'a Ayat-Ayat Keutamaan Al-Qur'an Ayat-Ayat Tazkiyatun Nafs Dan Hadits Keutamaan Al-Qur'an. Pustaka Al-Mubin.

Alma, Buchari. Kewirausahaan, (Bandung: Alfabeta, 2013).

"Arti Kata Pasar-Kamus Besar Bahasa Indonesia (KBBI) Online," diakses 29 Januari 2019, http://kbbi.web.id/pasar.

Amalia, Euis. 2013, "Mekanisme Pasar Dan Kebijakan Penetapan Harga Adil Dalam Perspektif Ekonomi Islam", Al-Iqtishaq, Vol. V, No. 1.

Diana, Ilfi Nur. Hadis - Hadis Ekonomi, (Malang: UIN Maliki Perss, 2012).

Farida, Ulfa Jamilatul. 2012, "Telaah Kritis Pemikiran Ekonomi Islam Terhadap Mekanisme Pasar Dalam Konteks Ekonomi Islam Kekinian", La Riba Jurnal Ekonomi Islam, Vol. VI, No. 2.

Idri. Hadis Ekonomi: Ekonomi Dalam Perspektif Hadis Nabi, (Jakarta: Kencana, 2015).

Kamaruddin. 2017, "Strategi Pemasaran Terhadap Peningkatan Volume Penjualan Gas Elpiji Perspektif Ekonomi Islam", Laa Maisyir, Vol. 4, No. 1.

Karim, Adiwarman A. Ekonomi Mikro Islami, (Jakarta: Rajawali Pers, 2016).

Kristaung, Robert. 2005, "Strategi Relationship Marketing: Kajian Teoritis Dan Implikasinya Dalam Manajemen Pemassaran", Jurnal Manajemen Krida Wacana, Vol. 5, No. 2.

Mardiyono, Aris. 2015, "Pengaruh Orientasi Pasar, Pembelajaran Organisasi Terhadap Keunggulan Bersing Dalam Meningkatkan Kinerja Pemasaran (Tinjauan Teoritis)", Serat Acitya: Jurnal Ilmiah, Vol. 04, No. 01.

Mauliana, Yenni Yuniarti, \& Sarah. 2012, "Strategi Pemasaran Produk Digital Printing Pada CV. FNB Digital Jambi", Vol. 1, No. 1.

Ihsan, Muh., Abdullah, Wahidah., \& Rusydi, Ulum, Bahrul. 2018, "Implementasi Prinsip Ekonomi Islam Oleh Pedagang Dalam Melakukan Penimbangan Sembako Di Pasar Soppeng", An-Nisbah: Jurnal Ekonomi Syariah, Vol. 05, No. 01.

Rosyidi, Suherman. Pengantar Teori Ekonomi Pendekatan Kepada Teori Ekonomi Mikro \& Makro, (Jakarta: Rajawali Pers, 2006).

Rozalinda. Ekonomi Islam Teori Dan Aplikasinya Pada Aktivitas Ekonomi, (Jakarta: Rajawali Pers, 2015).

Tahlohding, Sareeha. 2015, "Pemasaran Dalam Ekonomi Islam Studi Integrasi Dan Komprehensif", Hukum Islam, Vol. XV, No. 1.

Tamamudin. 2014, "Merefleksikan Teori Pemasaran Ke Dalam Praktik Pemasaran Syariah", Jurnal Hukum Islam (JHI), Vol. 12, No. 2.

Usman, Abdul Halim. Manajemen Strategi Syariah: Teori, Konsep, \& Aplikasi, (Jakarta: Zikrul Hakim, 2015).

Akila. 2014, "Menjaring Konsumen Dengan Konsep Beriontasi Strategi Pemasaran", Jurnal Media Wahana Ekonomika, Vol. 11, No. 3.

Jasman, \& Agustin, Rini. 2018, "Strategi Pemasaran Dalam Perspektif Ekonomi Islam (Studi Kasus Pedagang di Pasar Tradisional)", Khozana, Vol. 1, No. 1. 